\title{
PERKEMBANGAN MUATAN HAM DALAM KONSTITUSI DI INDONESIA
}

\section{Human Rights Content Development in the Constitution in Indonesia}

\author{
Muhammad Amin Putra \\ Fakultas Hukum, Universitas Indonesia \\ email: muhammadaminputra@gmail.com
}

\begin{abstract}
Briefly Human Rights can be divided into three categories, including: first, the first generation of Human Rights of a matter of civil rights and politics, secondly, about the rights of economic, social and cultural, and the third, representing the right to equality. Enforceability constitution in Indonesia including of the Constitution RIS of 1949 and Provisional Constitution RIS 1950, the Constitution of 1945, Amendment (I-IV) of the 1945 Constitution. Enforceability of human rights in the constitution in Indonesia has a different history in terms of the setting and the mention. Contents of Human Rights not only based on the rights of association, assembly, and contend yet more extensive and specific. The charge of human rights in the 1945 Constitution Amendment 1-4 nearly includes all the settings of the Universal Declaration in 1948.
\end{abstract}

Keywords: Human Rights, Constitution, Law

\section{abstrak}

HAM secara singkat dapat dibagi menjadi tiga kategori, diantaranya: pertama, generasi pertama HAM yang menyangkut masalah hak-hak sipil dan politik, kedua, mengenai hak-hak ekonomi, sosial dan budaya, dan ketiga, mewakili hak persamaan. Keberlakuan konstitusi di Indonesia dianatarnya Konstitusi RIS 1949 dan UUDS 1950, UUD Tahun 1945, UUD Tahun 1945 Amandemen (I-IV). Keberlakuan atas HAM dalam konstitusi di Indonesia memiliki sejarah yang berbeda dalam segi pengaturan dan penyebutan. Muatan HAM tidak hanya berdasarkan hak berserikat, berkumpul dan mengeluarkan pendapat namun lebih luas dan spesifik. Muatan HAM dalam UUD 1945 Amandemen 1-4 hampir memuat segala pengaturan DUHAM 1948.

Kata Kunci: Hak Asasi Manusia, Konstitusi dan Hukum 


\section{A. Pendahuluan}

Salah satu dinamika hukum Indonesia saat ini, diantaranya mengenai hak asasi manusia dan konstitusi. Antara HAM dan Konstitusi sangat berkaitan khususnya dalam konsep negara hukum. Dalam pemahaman bahwa hukum dalam pengertian yang paling umum adalah hubungan pasti yang berasal dari sifat segala sesuatu. Dalam pengertian ini semua wujud memiliki hukumnya ${ }^{1}$. Perkembangan negara yang berkembang diawal munculnya adalah negara kekuasaan (machtstaat) yang didasarkan pada hukum dari seorang raja dan berkembang kemudian menjadi negara hukum (rechtstaat, rule of law, goverment of law not of men). Maka, Dalam pengertian yang sama yaitu bahwa: 1. Otoritas publik hanya dapat menjalankan kewenangan berdasarkan perintah yang lebih tinggi yang dimungkinkan oleh hukum, dan 2. Hukum tersebut mengikat semua anggota masyarakat ${ }^{2}$.

Hukum menjadi instrumen penting dalam melindungi dan tegaknya HAM dalam negara. Dalam melindungi dan memastikan tegaknya HAM dalam negara, harus dipastikan hukum menjadi instrumen dalam pengawasan bahkan pembatasan kepada otoritas publik atau negara agar tidak terjadi abuse of power, dalam banyak kasus menjadi awal terjadinya pelanggaran HAM. Pengawasan terhadap negara menjadi pokok pertanyaan dari konstitusionalisme, sehingga pengontrolan terhadap negara tentu saja tidak dapat menjadi tujuan akhir dari usaha pengawasan kepada otoritas publik atau negara tanpa dilatarbelakangi sebuah tujuan. Menurut Hamdan Zoelva ${ }^{3}$ Konstitusionalisme merupakan faham pembatasan kekuasaan negara dalam tingkat yang lebih nyata dan operasional ${ }^{4}$, yang diimplementasikan dalam kehidupan bernegara.

Konstitusi sangat berkaitan erat dengan pembatasan-pembatasan kekuasaan. Sejarah terkait dengan Revolusi Perancis yang tidak terlepas dari buah pikiran Rousseau yang dalam karyanya Du Contract Social, memberikan sebuah gagasan bahwa antara hak warga negara dan pemerintah perlu adanya sebuah pembatasan. Rousseau menjelaskan, bahwa selain pribadi publik, kita juga harus menyadari pribadi-pribadi yang telah membangun negara, yang hidup dan kebebasanya secara alamiah bergantung pada pribadi publik tersebut. Selanjutnya, kita diikat untuk membedakan dengan tegas antara hak-hak warga negara dan pemerintah yang dihargai,

\footnotetext{
${ }^{1}$ Montesquieu, The Spirit of Laws, diterjemahkan M. Khoiril Anam, (Bandung: Nusa Media, 1977), hlm. 88

${ }^{2}$ Janedjri M. Gaffar, Demokrasi dan Pemilu di Indonesia, (Jakarta: Konstitusi Press, 2013), hlm. 47- 48

${ }^{3}$ Ketua Mahkamah Konstitusi Republik Indonesia Tahun 2013 - 2014

${ }^{4}$ Makalah yang disampaikan pada Seminar Negara Hukum di UGM Yogyakarta, tanggal 31 Mei 2009, dalam rangka memperingati hari lahrnya Pancasila.
} 
serta tanggung jawab yang harus dipenuhi warga negara dan hak-hak alamiah $^{5}$ yang seharusnya mereka nikmati sebagai manusia. Setiap pengabdian yang diberikan warga kepada negara langsung dibutuhkan pula oleh pemerintah. Namun, pemerintah tidak bisa menerapkan banyak larangan kepada warganya yang tidak bermanfaat bagi komunitas. ${ }^{6}$ Gagasan Rousseau disini merupakan hasil pemikiran dari kondisi negara yang sangat absolut di zamannya. Pembatasan kekuasaan (konstitusionalisme) dirasa paling tepat agar kekuasaan negara tidak memberangus kebebasan tiap-tiap individu.

Konstitusionalisme sebagai fungsi pembatasan kekuasaan pemerintahan. Gagasan konstitusionalisme memberikan motivasi yang kuat dalam meletakkan prinsip-prinsip fundamental mengenai pemerintahan berdasarkan konstitusi, dan menolak pemerintahan berdasarkan kekuasaan. Oleh Carl J Friedrich, "konstitusionalisme adalah sebuah gagasan yang menggangap pemerintah sebagai suatu kumpulan aktivitas yang diselenggarakan atas nama rakyat, yang tunduk pada pembatasan konstitusional"7. Konsensus yang menjamin tegaknya konstitusionalisme di zaman modern pada umumnya dipahami bersandar pada tiga elemen kesepakatan yaitu: 1) Kesepakatan tentang tujuan atau cita-cita bersama (the general goals of society or general acceptance of the same philosophy of government). 2) Kesepakatan tentang the rule of law sebagai landasan pemerintahan atau penyelenggaraan negara (the basis of government). 3. Kesepakatan tentang bentuk institusi-institusi dan prosedur-prosedur ketatanegaraan (the form of institutions and procedures) ${ }^{8}$. Gagasan konstitusionalisme berupa pembatasan kekuasaan pemerintahan yang diatur dalam konstitusi dapat menjamin adanya perlindungan HAM. Salah satunya dapat dilihat dalam perkembangan UUD 1945 sebagai konstitusi di Indonesia, yang memuat gagasan konstitusionalisme dan perlindungan HAM dalam tiap periode berlakunya UUD 1945, Konstitusi RIS, UUDS hingga kembali pada UUD 1945 hasil amandemen.

\footnotetext{
${ }^{5}$ Hukum alam (natural law) dapat dimaknai apa yang sifatnya alamiah, yang seharusnya terjadi. Hukum alam (natural law) seharusnya menjadi hukum yang mengatur untuk semua benda, termasuk manusia dan hubungan-hubungan manusia, http://www.ermanhukum.com/ Kuliah/Filsafat\%20Hukum\%20Ekonomi\%20Kul\%20II.pdf diakses pada 31 Maret 2015, pkl $11: 49$.

${ }^{6}$ Jean Jacques Rousseau, Du Contract Social, Terjemah Nino Cicero, Perjanjian Sosial, Cetakan Kedua (Jakarta: Transmedia, 2009), hlm. 50.

${ }^{7}$ John Pieris, Pembatasan Konstitusional Kekuasaan Presiden RI, (Jakarta: Pelangi Cendikia, 2007), hlm. 44. Lihat juga Carl J. Friedrich, Constitusional Goverment and Democracy: Theory and Practice in Europe and America, 5th edition (Mass: weltham, 1967)

${ }^{8}$ Jimly Asshidiqqie, Ideologi, Pancasila, dan Konstitusi, (Jakarta: Mahkamah Konstitusi, 2006).
} 
Jenis penelitian dalam penulisan hukum ini adalah penelitian hukum normatif atau penelitian hukum kepustakaan yaitu penelitian hukum yang dilakukan dengan cara meneliti bahan-bahan pustaka atau data sekunder yang terdiri dari bahan hukum primer. ${ }^{9}$. Pendekatan dalam penelitian hukum terdapat beberapa pendekatan, yaitu pendekatan perundang-undangan (statute approach), pendekatan historis (historical approach), pendekatan perbandingan (comparative approach) dan pendekatan konseptual (conceptual approach). ${ }^{10}$ Pendekatan penelitian yang digunakan adalah pendekatan historis dan konseptual.

\section{B. Pembahasan}

\section{Hak Asasi Manusia}

Perkembangan mengenai HAM secara singkat dapat dibagi menjadi tiga kategori, diantaranya: pertama, generasi pertama HAM yang menyangkut masalah hak-hak sipil dan politik, kedua, mengenai hak-hak ekonomi, sosial dan budaya, dan ketiga, mewakili hak persamaan. Khususnya mengenai HAM generasi kedua, hak-hak ini muncul agar negara aktif memberikan perlindungan dan pemenuhan HAM. Hak asasi manusia yang pertama berangkat dari mewakili hak-hak sipil dan politik ${ }^{11}$ yang dimulai sejak periode Yunani Klasik. Namun konsepsi modern yang kemudian menjelma menjadi HAM, khususnya hak sipil dan politik ${ }^{12}$. Hakhak ini muncul dari tuntutan untuk melepaskan diri dari kungkungan kekuasaan absolutisme Negara dan kekuatan-kekuatan social lainnya ${ }^{13}$.

Kemudian berkembang hak asasi manusia yang kedua yaitu hak ekonomi, social dan budaya. Yang muncul dari tuntutan agar Negara memberikan pemenuhan akan hak-hak dasar warga Negara. Dalam bagian luas, ia merupakan respon terhadap pelanggaran-pelanggaran dan penyelewengan-penyelewengan dari perkembangan kapitalis dan menggarisbawahinya; tanpa kritik yang esensial, konsepsi kebebasan individual yang mentoleransi-bahkan melegitimasi, eksploitasi kelas pekerja

\footnotetext{
${ }^{9}$ Soerjono Soekanto dan Sri Mahmudji, Penelitian Hukum Normatif: Suatu Tinjauan Singkat, (Jakarta, CV. Rajawali, 1985), hlm 34-35 dan 41.

${ }^{10}$ Peter Mahmud Marzuki. Penelitian Hukum, (Jakarta: Kencana, 2006). hlm. 93.

11 Terutama yang berasal dari kaum reformis yang dikemukakan pada awal abad ke-17 dan ke-18, yang berkaitan dengan revolusi-revolusi Inggris, Amerika, dan Perancis. Dipengaruhi filsafat politik individualism liberal dan doktrin social ekonomi laissez-faire, lihat Pasal 2-21 Universal Declaration of Human Rights.

${ }^{12}$ LG Saraswati, et. Al, Hak Asasi Manusia, Teori Hukum Kasus, (Jakarta: Departemen Filsafat, Fakultas Ilmu Pengetahuan Budaya Universitas Indonesia, 2006), hlm. 9.

${ }^{13}$ Rhona K. Smith., et. Al, Hukum Hak Asasi Manusia, (Yogyakarta: Pusat Studi Hak Asasi Manusia Universitas Islam Indonesia, 2008), hlm. 15.
} 
dan masyarakat kolonial ${ }^{14}$. Munculnya generasi HAM ketiga dilandasi oleh rasa solidaritas atau hak solidaritas atau hak bersama dan merupakan rekonseptualisasi dari dua generasi HAM sebelumnya ${ }^{15}$. Tercermin dalam Pasal 28 Universal Declaration of Human Rights ${ }^{16}$.

HAM yang melekat pada diri manusia itu sendiri mempunyai berbagai hak, hak-hak dasar dari HAM itu meliputi:

a. Hak asasi pribadi atau "the personal rights", yang meliputi kebebasan menyatakan pendapat, memeluk agama, bergerak dan sebagainya.

b. Hak asasi ekonomi atau "the property rights", yaitu hak untuk memiliki sesuatu, membeli dan menjual serta memanfaatkannya.

c. Hak asasi untuk mendapatkan perlakuan yang sama dalam hukum dan pemerintahan atau yang biasa disebut "the rights of legal equality".

d. Hak-hak politik atau "the political rights", yaitu hak untuk ikut serta dalam pemerintahan, hak pilih (memilih dan dipilih dalam pemilihan umum), hak mendirikan partai politik dan sebagainya.

e. Hak-hak asasi sosial dan kebudayaan atau "the social and cultural rights", misalnya hak untuk memilih pendidikan, mengembangkan kebudayaan dan sebagainya.

f. Hak-hak asasi untuk mendapatkan perlakuan tata cara peradilan dan perlindungan atau "the procedural rights", misalnya peraturan dalam hal penangkapan, penggeledahan, peradilan dan sebagainya. ${ }^{17}$

\section{Konstitusi, Negara Hukum dan Perkembangan HAM}

Konsep negara hukum indonesia diwujudkan dalam bentuk perlindungan terhadap warga negara dalam UUD Negara Republik Indonesia $^{18}$. Negara hukum merupakan usaha pembatasan absolutisme negara (raja) ${ }^{19}$ melalui seperangkat aturan dalam konstitusi (konstitusionalisme) ${ }^{20}$ Menurut Sri Soemantri, pada umumnya materi

\footnotetext{
${ }^{14}$ Satya Arinanto, Hak Asasi Manusia Dalam Transisi Politik di Indonesia, (Jakarta: Pusat Studi Hukum Tata Negara Fakultas Hukum Universitas Indonesia, 2008), hlm. 80.

${ }^{15}$ Ibid.

16 Setiap orang berhak atas suatu tatanan sosial dan internasional di mana hak-hak dan kebebasan-kebebasan yang termaktub di dalam Deklarasi ini dapat dilaksanakan sepenuhnya.

${ }^{17}$ Dardji Darmodihardjo dan Santiaji, Pancasila, (Usaha Nasional, 1981), hlm. 80-81.

${ }^{18}$ Lihat bagian Pembukaan UUD 1945: "Kemudian dari pada itu untuk membentuk suatu Pemerintah Negara Indonesia yang melindungi segenap bangsa Indonesia dan seluruh tumpah darah Indonesia dan untuk memajukan kesejahteraan umum, mencerdaskan kehidupan bangsa, dan ikut melaksanakan ketertiban dunia yang berdasarkan kemerdekaan, perdamaian abadi dan keadilan social..."

${ }^{19}$ A. Mukhtie Fajar, Tipe Negara Hukum, Bayumedia Publishing, Malang, 2001, hlm. 19.

${ }^{20}$ Jimly Asshiddiqie, Konstitusi dan Konstitusionalisme Indonesia, Mahkamah konstitusi RI dan Pusat Studi Hukum Tata Negara Fak. Hukum UI, Jakarta, 2004, hlm. 1.
} 
konstitusi atau undang-undang dasar mecakup tiga hal yang fundamental:1) Adanya jaminan terhadap HAM dan warganya; 2) Ditetapkannya susunan ketatanegaraan suatu negara yang bersifat fundamental; 3) Adanya pembagian dan pembatasan tugas ketatanegaraan yang juga bersifat fundamental. ${ }^{21}$

Eksistensi UUD 1945 sebagai konstitusi, menurut A.A.H. Struycken Undang-Undang Dasar (grondwet) sebagai konstitusi tertulis merupakan sebuah dokumen formal yang berisi: 1) Hasil perjuangan politik bangsa di waktu yang lampau; 2) Tingkat-tingkat tertinggi perkembangan ketatanegaraan bangsa; 3) Pandangan tokoh-tokoh bangsa yang hendak diwujudkan, baik sekarang maupun untuk masa yang akan datang; 4) Suatu keinginan, dengan mana perkembangan kehidupan ketatanegaraan bangsa hendak dipimpin ${ }^{22}$.

Muatan dalam UUD 1945 berdasarkan pendapat A.A.H. Struycken telah memuat pandangan, keinginan dan perkembangan kehidupan negara oleh tokoh-tokoh bangsa, yang menginginkan terbentuknya negara hukum yang melindungi HAM. Dalam perkembangannya Istilah negara hukum dalam berbagai literatur tidak bermakna tunggal, tetapi dimaknai berbeda dalam tempus dan locus yang berbeda, sangat tergantung pada idiologi dan sistem politik suatu negara. Karena itu Tahir Azhary, dalam penelitiannya sampai pada kesimpulan bahwa istilah negara hukum adalah suatu genus begrip yang terdiri dari dari lima konsep, yaitu konsep negara hukum menurut Al Qur'an dan Sunnah ${ }^{23}$ yang diistilahkannya dengan nomokrasi Islam $^{24}$, negara hukum menurut konsep Eropa kontinental yang disebut

${ }^{21}$ C. Anwar, Teori dan Hukum Konstitusi, (Malang: In-Trans Publishing, 2011), hlm. 61.

${ }^{22}$ Dahlan Thaib., et. al., Teori dan Hukum Konstitusi, (Jakarta: PT Rajagrafindo Persada), hlm. 15

${ }^{23}$ Dalam islam terdapat hukum-hukum yang juga mengatur tentang HAM diantaranya Hak untuk Hidup (al-An'am: 151), Hak Persamaan derajat (al-Hujurat: 13), Hak memperoleh keadilan (al-Maidah:, 8)

${ }^{24} \mathrm{Hal}$ ini dapat terlihat dalam Universal Islamic Human Rights yang dibuat 19 September 1981 menyebutkan beberapa macam hak, yaitu: Right to Life, Right to Freedom, Right to Equality and Prohibition Against Impermissible Discrimination, Right to Justice, Right to Fair Trial, Right to Protection Against Abuse of Power, Right to Protection Against Torture, Right to Protection of Honour and Reputation, Right to Asylum, Rights of Minorities, Right and Obligation to Participate in the Conduct and Management of Public Affairs, Right to Freedom of Belief, Thought and Speech, Right to Freedom of Religion, Right to Free Association, The Economic Order and the Rights Evolving Therefrom, Right to Protection of Property, Status and Dignity of Workers, Right to Social Security, Right to Found a Family and Related Matters, Rights of Married Women, Right to Education, Right of Privacy, Right to Freedom of Movement and Residence. 
rechtstaat, konsep rule of law, konsep socialist legality serta konsep negara hukum Pancasila ${ }^{25}$.

Pembagian dalam beberapa locus dan tempus yang berbeda tersebut dapat digolongkan menjadi dua kelompok besar yang diterapkan oleh negara-negara, yaitu rechtstaat dan rule of law. Moh. Mahfud MD menyatakan bahwa negara hukum dalam konsepsi rechtstaat berakar pada sistem hukum civil law yang menitikberatkan pada administrasi dan mengutamakan wetmatigheid dan rechtmatigheid. Di sisi lain, the rule of law berakar pada sistem hukum common law yang menitikberatkan pada aspek yudisial dan mengutamakan prinsip equality before the law ${ }^{26}$. Dalam pandangan A. V. Dicey, merumuskan tiga makna the rule of law, pertama, the rule of law bermakna supremasi absolut atau predomnasi hukum dan meniadakan kesewenang-wenangan (arbitrariness). Kedua, the rule of law, bermakna persamaan kedudukan di depan hukum (equality before the law). Ketiga, the rule of law berarti pengakuan hukum konstitusi bukan merupakan sumber bagi hak asasi manusia, melainkan sebaliknya, sebagai konsekuensi dari pengakuan atas hak asasi manusia ${ }^{27}$.

Pendapat lain oleh Friderich Julius Stahl mengemukakan empat unsur rechtstaat, yaitu: 1) Perlindungan HAM; 2) Pemisahan atau pembagian kekuasaan untuk menjamin hak-hak itu; 3) Pemerintahan berdasarkan peraturan-peraturan; 4) Peradilan administrasi dalam perselisihan ${ }^{28}$ Salah satu ciri negara hukum, yang dalam bahasa inggris disebut rule of law atau dalam bahasa Belanda disebut rechtstaat, ciri pembatasan penyelenggaraan kekuasaan negara ${ }^{29}$. Ciri-ciri negara hukum menurut Franz Magnis Suseno adalah: 1) Kekuasaanya dijalankan sesuai dengan hukum positif yang berlaku; 2) Kegiatan negara berada di bawah kontrol kekuasaan kehakiman yang efektif; 3) Berdasarkan sebuah undang-undang dasar yang menjamin HAM, dan; 4) Menurut pembagian kekuasaan ${ }^{30}$. Demikian pula Scheltema menyatakan bahwa unsur-unsur Rechtsstaat adalah:

a. Kepastian hukum;

b. Persamaan;

c. Demokrasi. ${ }^{31}$

${ }^{25}$ Makalah yang disampaikan pada Seminar Negara Hukum di UGM Yogyakarta, tanggal 31 Mei 2009, dalam rangka memperingati hari lahrnya Pancasila.

${ }^{26}$ Janedjri M. Gaffar, Demokrasi dan Pemilu di Indonesia, (Jakarta: Konstitusi Press, 2013), hlm. 56.

${ }^{27}$ Ibid., Janedjri M. Gaffar, hlm. 52.

${ }^{28}$ Ibid., Janedjri M. Gaffar, hlm. 55.

${ }^{29}$ Jimly Asshiddiqie, Pengantar Hukum Tata Negara Jilid II, (Jakarta: Sekretariat Jendral dan Kepaniteraan Mahkamah Konstitusi Republik Indonesia, 2006), hlm. 11.

${ }^{30}$ Op. Cit., Janedjri M. Gaffar, hlm. 50 - 51.

${ }^{31}$ Ibid., hlm. 70. 
Bahwa pemerintah yang harus melayani kepentingan publik warga negaranya, bukan sebaliknya warga negara melayani pemeritahnya. Selanjutnya, Philipus M. Hadjon mengemukakan ciri-ciri Rechtsstaat adalah:

a. Adanya undang-undang dasar atau konstitusi yang memuat ketentuan tertulis tentang hubungan antara penguasa dan rakyat.

b. Adanya pembagian kekuasaan negara.

c. Diakui dan dilindunginya hak-hak kebebasan rakyat. ${ }^{32}$

Dalam kaitan ini, Sri Soemantri juga mengemukakan adanya empat unsur terpenting negara hukum, yaitu:

a. Pemerintah dalam melaksanakan tugas dan kewajibannya harus berdasar atas hukum atau peraturan perundang-undangan.

b. Adanya jaminan terhadap hak-hak asasi manusia (warga negara).

c. Adanya pembagian kekuasaan (distribution of power) dalam negara.

d. Adanya pengawasan (dari badan-badan peradilan). ${ }^{33}$

Sehingga HAM dapat dipahami sebagai bagian dalam konstitusi dan merupakan hal yang wajib dilindungi oleh konstitusi itu sendiri. Masyur Efendi menjelaskan pengertian hak asasi manusia dari berbagai pendapat diantaranya: ${ }^{34}$

The United Nations Centre for Human Right (PBB) defines: human rights as those rights which are inherent in our nature and without which we can not live as human beings.

Human Rights have also be defined as moral rights of the higher order stemming from socially shared moral conceptions of the nature of the human person and the condition necessary for a life of dignity.

Nickel; characerizes human rights as norms which are definite, high priority, universal, existing and valid independently of recognition or implementation in the customs or legal systems of particular countries.

Szabo; puts human rights within the framework of contitutional law, the purpose of which is to defend by institutional means the rights of human beings against abuses of power committed by the organs of the state and at the same time to promote the establishment of humane living conditions and the

${ }^{32}$ Philipus M. Hadjon, Perlindungan Hukum Bagi Rakyat Indonesia, (Surabaya: PT. Bina Ilmu, 1987), hlm. 76.

${ }^{33}$ Sri Soemantri (a), Bunga Rampai Hukum Tata Negara Indonesia, (Bandung: Alumni, 1992), hlm. 29.

34 A. Masyhur Effendi, Perkembangan Dimensi Hak Asasi Manusia (HAM) dan Proses Dinamika Penyusunan Hukum Hak Asasi Manusia (HAKHAM), (Ghalia Indonesia, Jakarta, 2005), hlm. 47 
multidimensional development of human personality. Human rights are those minimal rights which every individual must have against the state or other public authority by virtue of his being a 'member of the human family', irrespective of any other consideration. ${ }^{35}$

Human rights are universal, that is, they belong to each of us regardless of ethnicity, race, gender, sexuality, age, religion, political conviction, or type of government.

Human rights are incontrovertible, that is they are absolute and innate. They are not grants from states and thus cannot be removed or denied by any political authority, and they do not require, and are not negated by the absence of, any corresponding duties. Human rights are subjective. They are the properties of individual subjects who possess the because of their capacity for rationality, agency and autonomy. ${ }^{36}$

Kuntjoro Purbopranoto mengartikan HAM sebagai hak-hak yang dimiliki manusia menurut kodratnya, yang tidak dapat dipisahkan dari pada hakekatnya dan karena itu bersifat suci. ${ }^{37}$ Jan Materson sebagaimana dikutip Baharudin Lopa mengartikan HAM sebagai hak yang melekat pada manusia, yang tanpa dengannya manusia mustahil hidup sebagai "Human right which are inheren in our nature and without which we can not live as human being." Baharudin Lopa mengartikan prasa "mustahil hidup sebagai manusia" dengan "mustahil hidup sebagai manusia di samping mempunyai hak juga harus bertanggung jawab atas segala yang dilakukannya." 38

Al Maududi sebagaimana dikutip Ahmad Kosasih mengartikan HAM sebagai hak-hak yang diberikan Allah sejak manusia lahir dan karenanya tidak terdapat satu orang atau lembagapun yang berhak mencabut atau membatalkannya. ${ }^{39}$

Pasal 1 angka 1 Undang-undang Nomor 39 Tahun 1999 tentang Hak Asasi Manusia ${ }^{40}$ mengartikan HAM sebagai :

35 Durga Das Basu, Human Rights in Constitutional Law, second edition, (edited by: Bhagabati Prosad Banerjee \& Ashish Kumar Massey, Wadha Nagpur, 2003). hlm. 8.

${ }^{36}$ Darren J O'byrne, Human Rights an Introduction, (Pearson Education, Singapore, 2004) hlm. 27.

${ }^{37}$ Kuntjoro Purbopranoto, Hak-hak Asasi Manusia dan Pancasila, Pradya Paramita, Jakarta, 1982, hlm. 19.

38 Baharudin Lopa, Al Quran dan Hak-hak Azasi Manusia, PT. Dhana Bakti Prima Yasa, Yogyakarta, 1996, hlm. 1

39 Ahmad Kosasih, HAM dalam Prespektif Islam; Menyingkap Persamaan dan perbedaan Antara Islam dan Barat, Salemba Diniyah, Jakarta, 2003, hlm. xvii.

${ }^{40}$ Lembaran Negara RI Tahun 1999 Nomor 165, Tambahan Lembaran Negara RI Nomor 3886. 
“...Seperangkat hak yang melekat pada hakikat dan keberadaan manusia sebagai mahluk Tuhan Yang Maha Esa dan merupakan anugerahNya yang wajib dihormati, dijunjung tinggi dan dilindungi oleh negara, hukum, Pemerintah, dan setiap orang demi kehormatan serta perlindungan harkat dan martabat manusia.

Senada dengan makna tersebut terdapat dalam dasar pertimbangan undang-undang dimaksud yang menyebutkan bahwa :

"...hak asasi manusia merupakan hak dasar yang secara kodrati melekat pada diri manusia, bersifat universal dan langgeng, oleh karena itu harus dilindungi, dihormati, dipertahankan, dan tidak boleh diabaikan, dikurangi, atau dirampas oleh siapapun.

Sehingga HAM sebagaimana dikatakan Szabo HAM tanpa dibingkai dalam hukum konstitusi akan menimbulkan kesewenang-wenangan. Penegakan HAM di Indonesia mengalami fase-fase yang berbeda menurut sejarah. Dikarenakan Konstitusi itu tidak merupakan sumber dari hak-hak asasi manusia dan jika hak-hak asasi manusia itu diletakkan dalam konstitusi, itu hanya sebagai penegasan bahwa hak asasi manusia itu harus dilindungi ${ }^{41}$. Jika tidak, tentu saja dapat melanggar hak warga negara. Maka penegakan HAM di Indonesia berdasarkan ketentuan konstitusional dapat dibagi menjadi 4 fase, diantaranya:

\section{a. Perdebatan HAM oleh Pendiri Bangsa (UUD Tahun 1945)}

Dalam perkembangan masa kemerdekaan di Indonesia, saat kemerdekaan tahun 1945, Indonesia memberlakukan UUD 1945. Sebelum berlakunya UUD 1945 sebagai falsafah Negara telah muncul perdebatan yang dilontarkan para pendiri bangsa, diantaranya dalam penyampaian Soekarno sebagai anggota BPUPK, sebagai berikut ${ }^{42}$ :

Kenapa tidak dituliskan hak Individu bagi orang- orang Indonesia? Tuan-tuan yang terhornat, inilah justru yang hendak saya terangkan. Inilah yang menjadi sumbernya malapetaka-malapetaka di dunia ini. Negara - negara di Eropa dan Amerika, didirikan diatasnya dasar hak kedaulatan staat yang dinamakan staat souvereinteit. Sebenarnya ini, sebagai yang diterangkan oleh Prof. Soepomo kemarin, sudah mengandung konflik. Hak kemerdekaan manusia sebagai individu, dan hak kemerdekaan kedaulatan staat sebagai satu badan pula.

${ }^{41}$ Fajar Laksono et.al, Status Keistimewaan Daerah Istimewa Yogyakarta dalam Bingkai Demokrasi Berdasarkan Undang-Undang Dasar 19451 (Studi Kasus Pengisian Jabatan Kepala Daerah dan Wakil Kepala Daerah), Jakarta: Pusat Penelitian dan Pengkajian Mahkamah Konstitusi Republik Indonesia, 2011. hlm. 7

${ }^{42}$ RM. A.B. Kusuma, Lahirnya Undang - Undang Dasar 1945, Edisi Revisi, (Jakarta: Fakultas Hukum Universitas Indonesia, 2009), hlm. 349. 
Anggota BPUPK lainnya, Mohammad Hatta menyatakan kebutuhan akan HAM yang dicantumkan dalam UUD akan menimbulkan kekuasaan tidak terbatas pada negara ${ }^{43}$. Tercapainya kesepakatan yaitu mencantumkan muatan $\mathrm{HAM}^{44}$ yang sebelumnya ditentang oleh Soekarno karena dinilai sebagai cerminan nilai barat dan bertolak dengan cita Negara kekeluargaan. Meskipun tidak secara langsung memuat pencantuman HAM, namun muatan pasal tersebut cukup menjadi bagian dari cerminan HAM di Indonesia saat itu. Terkait pencantuman HAM ada tiga pandangan diantaranya: pertama, mereka yang berpandangan bahwa UUD 1945 tidak memberikan jaminan atas HAM secara komprehensif; kedua, mereka berpandangan UUD 1945 memberikan jaminan atas HAM secara komprehensif; dan ketiga, berpandangan bahwa UUD 1945 hanya memberikan pokok-pokok jaminan atas $\mathrm{HAM}^{45}$.

Pandangan pertama didukung oleh Mahfud MD dan Bambang Sutiyoso. Hal ini didasarkan bahwa istilah HAM tidak ditemukan secara eksplisit di dalam Pembukaan, Batang Tubuh, maupun Penjelasannya. Justru menurut Sutiyoso ${ }^{46}$, di dalam UUD 1945 hanya ditemukan pencantuman dengan tegas perkataan hak dan kewajiban warga Negara, dan hak-hak $\mathrm{DPR}^{47}$. Pandangan kedua didukung oleh Soedjono Sumobroto dan Marwoto, Azhary dan Dahlan Thaib. Sumobroto dan Marwoto mengatakan UUD 1945 mengangkat fenomena HAM yang hidup di kalangan masyarakat, atas dasar itu HAM yang tersirat di dalam UUD 1945 bersumber pada falsafah dasar dan pandangan hidup bangsa, yaitu pancasila ${ }^{48}$. Kelompok ketiga didukung oleh Kuntjoro Purbopranoto, G. J Wolhoff, dan M. Solly Lubis. Menurut Kuntjoro, jaminan HAM bukan tidak ada, melainkan dalam ketentuanketentuannya UUD 1945 mencantumkan secara tidak sistematis ${ }^{49}$.

43 Dalam pandangannya, perlunya diatur mengenai pasal tentang warga Negara yang memberikan hak agar tiap-tiap warga Negara jangan takut mengeluarkan suaranya. Hal ini perlu untuk menjaga supaya Negara Negara tidak menjadi Negara kekuasaan, karena Negara didasarkan atas kedaulatan rakyat. Ibid., hlm. 355

${ }^{44}$ Lihat Pasal 28 UUD 1945 sebelum amandemen; Kemerdekaan berserikat dan berkumpul, mengeluarkan pikiran dengan lisan dan tulisan dan sebagainya ditetapkan dengan undangundang.

45 Majda El-Muhtaj, Hak Asasi Manusia dalam Konstitusi Indonesia, (Jakarta: Prenada Media, 2005), hlm. 95.

${ }^{46}$ Ibid.

${ }^{47}$ Lihat Pasal 21: ayat (1) Anggota-anggota Dewan Perwakilan Rakyat berhak memajukan rancangan undang-undang, Pasal 29: ayat (1) Negara menjamin kemerdekaan tiap-tiap penduduk untuk memeluk agamanya masing-masing dan untuk beribadat menurut agamanya dan kepercayaannya itu, Pasal 30:ayat (1) Tiap-tiap warga negara berhak dan wajib ikut serta dalam usaha pembelaan negara, dan Pasal 31: Ayat (1) Tiap-tiap warga negara berhak mendapat pengajaran. Dalam UUD 1945 sebelum amandemen.

${ }^{48}$ Majda El-Muhtaj, Ibid., hlm. 96.

${ }^{49}$ Ibid. 
Dalam pandangan lainnya Ismail Sunny melihat banyak kandungan dalam UUD 1945 yang berkaitan dengan HAM. Lihatlah pada pembukaan (preambule) misalnya, alinea pertama dengan pengakuan adanya "freedom to be free ${ }^{, 50}$, alinea kedua dari pembukaan yang menyebutkan Indonesia sebagai Negara yang adil. Alinea ketiga yang menekankan bahwa rakyat Indonesia mengatakan supaya berkehidupan berkebangsaan yang bebas adalah salah satu dari pengakuan dan perlindungan hak asasi manusia, yang mengandung persamaan dalam bentuk politik. Alinea keempat dan terakhir, yang berisi dalam garis-garis besarnya pengakuan dan perlindungan hak asasi manusia dalam seluruh bidang-bidangnya yaitu politik, hukum, social, ekonomi, kultural dan pendidikan ${ }^{51}$. Pada saat itu pula masalah HAM belum menjadi persoalan kehidupan bangsa dikarenakan Indonesia masih dalam upaya mempertahankan kemerdekaannya dari agresi militer Belanda.

\section{b. Euforia Pengakuan HAM (Konstitusi RIS 1949 dan UUDS 1950)}

Bertolak belakang dengan nuansa kebhatinan pembuatan UUD 1945, pembentukan Konstitusi RIS 1949 berada pada masa euforia pengakuan dan perlindungan HAM yang berselang setahun setelah DUHAM PBB 1948. Konstitusi RIS termuat 22 pasal mengenai $\mathrm{HAM}^{52}$ dalam batang tubuh Konstitusi RIS. Sehingga dalam konstitusi RIS sangat terlihat implementasi muatan DUHAM tahun 1948.

Dalam perkembangannya selang setahun, maka dibentuklah UUDS 1950 dengan diundangkannya UU No. 7 Tahun 1950 tentang Perubahan Konstitusi Sementara Republik Indonesia Serikat Menjadi Undang-Undang Dasar Sementara Republik Indonesia ${ }^{53}$ yang berisi 146 pasal. Menurut catatan Soepomo, setidaknya terdapat tiga perbedaan mendasar Konstitusi RIS 1949 dengan UUDS 1950 dalam hal penegasan tentang HAM. Pertama, hak dasar mengenai kebebasan beragama atau keisyafan bathin dan pikiran meliputi kebebasan bertukar agama atau keyakinan, dan sebagainya tertuang pada Pasal 18 Konstitusi RIS ${ }^{54}$ oleh UUDS 1950, pernyataan meliputi kebebasan bertukar agama atau keyakinan tidak ditegaskan lagi.

\footnotetext{
${ }^{50}$ Alinea pertama pembukaan UUD 1945, Bahwa sesungguhnya kemerdekaan itu ialah hak segala bangsa dan oleh sebab itu, maka penjajahan di atas dunia harus dihapuskan, karena tidak sesuai dengan peri-kemanusiaan dan peri-keadilan.

${ }^{51}$ Ismail Sunny, Hak Asasi Manusia, (Jakarta: Yarsif Watampone, 2004), hlm. 2

${ }^{52}$ Pasal 7 ayat (1), (2), (3), (4), Pasal 8, Pasal 9 ayat (1) dan (2), Pasal 10, Pasal 11, Pasal 12, Pasal 13 ayat (1), (2), Pasal 14 ayat (1), (2), (3), Pasal 18, Pasal 19, Pasal 20, Pasal 21 ayat (1), Pasal 25 ayat (1), (2), Pasal 27 ayat (2), dan Pasal 28.

${ }^{53}$ Lihat dalam Pasal I Konstitusi Sementara Republik Indonesia Serikat diubah menjadi Undang-undang Dasar Sementara Republik Indonesia, sehingga naskahnya berbunyi sebagai berikut..

${ }^{54}$ Setiap orang berhak atas kebebasan agama, keinsyafan batin dan pikiran. Dalam Pasal 18 Konstitusi RIS dijelaskan secara rinci mengenai kebebasan bertukar agama atau keyakinan.
} 
Kedua, di dalam Pasal 21 UUDS $1950^{55}$ diatur perihal hak berdemontstrasi dan hak mogok yang sebelumnya tidak terdapat pada konstitusi RIS, dan ketiga, dasar perekonomian sebagaimana dimuat dalam Pasal 33 UUD 1945, diadopsi ke dalam Pasal 38 UUDS 195056. Dalam UUDS 1950 juga memuat hal-hal yang merupakan perkembangan dari HAM itu sendiri, disamping pengakuan terhadap individu-individu sebagai pencerminan HAM, diatur mengenai Materi HAM dalam UUD 1950 terdiri dari 36 Pasal yang terbagi dalam dua bab, Bagian V tentang Hak-hak dan Kebebasan Dasar Manusia, yakni dari Pasal $7^{57}$-Pasal $34^{58}$ dan Bagian VI tentang Asas-asas Dasar, yaitu Pasal 35 $5^{59}$-Pasal $43^{60}$. Hak-hak dasar manusia dalam UUDS 1950 tidak saja mencakup hak asasi, tetapi terdapat kewajiban asasi, serta terdapat sejumlah larangan atas adanya pelanggaran HAM, namun dalam UUDS 1950 mengatur adanya hak milik sebagai fungsi sosial atau ketentuan-ketentuan lainnya yang bersifat sosial masyarakat dan hakhak ${ }^{61}$. Dalam sejarah Konstitusi Indonesia berturut-turut KRIS (1949) dan UUDS 1950 mengatur HAM secara rinci, karena ditetapkan sesudah diumumkannya Universal Declaration of Human Rights, maka dapat dikatakan "Konstitusi yang dipengaruhi oleh Deklarasi HAM sedunia itu. Hubungan saling mempengaruhi antara konstitusi di dunia dengan Universal

${ }^{55}$ Hak berdemonstrasi dan mogok diakui dan diatur dengan undang-undang.

${ }^{56}$ Op. Cit., Majda El-Muhtaj, hlm. 108.

${ }^{57}$ (1) Setiap orang diakui sebagai manusia pribadi terhadap undang-undang. (2) Sekalian orang berhak menuntut perlakukan dan perlindungan yang sama oleh undang-undang. (3) Sekalian orang berhak menuntut perlindungan yang sama terhadap tiap-tiap pembelakangan dan terhadap tiap-tiap penghasutan untuk melakukan pembelakangan demikian. (4)Setiap orang berhak mendapat bantuan-hukum yang sungguh dari hakim-hakim yang ditentukan untuk itu, melawan perbuatan perbuatan yang berlawanan dengan hak-hak dasar yang diperkenankan kepadanya menurut hukum.

${ }^{58}$ Tiada suatu ketentuanpun dalam bagian ini boleh ditafsirkan dengan pengertian, sehingga sesuatu penguasa, golongan atau orang dapat memetik hak dari padanya untuk mengusahakan sesuatu apa atau melakukan perbuatan berupa apapun yang bermaksud menghapuskan sesuatu hak atau kebebasan yang diterangkan dalamnya.

${ }^{59}$ Kemauan Rakyat adalah dasar kekuasaan penguasa; kemauan itu dinyatakan dalam pemilihan berkala yang jujur dan yang dilakukan menurut hak-pilih yang bersifat umum dan berkesamaan, serta dengan pemungutan suara yang rahasia ataupun menurut cara yang juga menjamin kebebasan mengeluarkan suara.

${ }^{60}(1)$ Negara berdasar atas Ke-Tuhanan Yang Maha Esa. (2). Negara menjamin kemerdekaan tiap-tiap penduduk untuk memeluk agamanya masing-masing dan untuk beribadat menurut agamanya dan kepercayaannya itu. (3) Penguasa memberi perlindungan yang sama kepada segala perkumpulan dan persekutuan agama yang diakui. (4) Pemberian sokongan berupa apapun oleh penguasa kepada penjabat-penjabat agama dan persekutuan-persekutuan atau perkumpulan-perkumpulan agama dilakukan atas dasar sama hak.(5) Penguasa mengawasi supaya segala persekutuan dan perkumpulan agama patuh-taat kepada undang-undang termasuk aturan-aturan hukum yang tak tertulis.

${ }^{61}$ Lihat Pasal 26 dan 27 UUDS 1950 
Declaration of Human Rights digambarkan oleh Henc van Maarseveen sebagai berikut: ${ }^{62}$

\begin{tabular}{|c|} 
Konstitusi \\
Sebelum 1948 \\
Mempengaruhi
\end{tabular}$\rightarrow \begin{gathered}\text { Universal } \\
\text { Declaration of } \\
\text { Human Rights }\end{gathered} \rightarrow \begin{gathered}\text { Konstitusi Sesudah } \\
\text { 1946 Dipengaruhi }\end{gathered}$

\section{c. Anomali Kekuasaan dan HAM (UUD Tahun 1945)}

Masa perkembangan HAM dalam konstitusi di Indonesia tidak banyak berkembang ketika memasuki era Orde Baru, ketika konstitusi kembali pada UUD 1945. Sebagaimana pengaturan HAM menurut UUD 1945 hanya mengatur dalam Pasal 28 UUD 1945, namun yang menjadi permasalahan ketika bagaimana peran Negara melakukan penegakan dan perlindungan terhadap HAM warga Negara.

Hal ini dipahami bahwa awal kepemimpinan Soeharto yang dimulai tahun 1966 masih dibayangi berbagai persoalan politik, keamanan dan ekonomi dalam negeri ${ }^{63}$. Dalam praktik bernegara, terlaksananya HAM secara baik dan bertanggung jawab sangat bergantung keada political will, political commitmen dan political action dari pelanggaran Negara ${ }^{64}$. Namun keadaan ini berlanjut dengan pengekangan hingga pelanggaran hak asasi manusia, yang secara umum dikelompokkan menjadi dua bentuk, diantaranya:

1) pengekangan kebebasan berserikat, berkumpul dan mengeluarkan pendapat.

2) penghilangan dan pembunuhan sejumlah orang tanpa dasar hukum.

Pada saat itu perkembangan HAM yang tidak terlalu pesat sangat diakui karena pengaruh konfigurasi politik yang represif. Sehingga, mengenai HAM tidak saja tidak dilakukan penegakan bahkan adanya pelanggaran HAM. Dalam hal ini banyak ditandai banyaknya pelanggaran diantaranya:

1) Kasus Trisakti dan Semanggi Mei 1998 dan November 1997;

2) Kasus marsinah;

3) Kasus Talangsari di Lampung;

4) Kasus Petrus dll ${ }^{65}$.

62 Dewa Gede Atmadja, Hukum Konstitusi Problematika Konstitusi Indonesia Sesudah Perubahan UUD 1945, (Malang: Setara Press, 2010), hlm. 199.

${ }^{63}$ Ganewati Wuryandari, et al., Politik Luar Negeri Indonesia di Tengah Pusaran Politik Domestik, (Jakarta: Pustaka Pelajar - P2P LIPI), Hlm. 129.

${ }^{64}$ Majda El Muhtaj, Dimensi-Dimensi HAM Mengurai Hak Ekonomi, Sosial, dan Budaya, (Jakarta: Rajawali Pers, 2008), hlm. 60.

${ }^{65}$ Dalam kasus-kasus diatas aksi pelanggaran HAM tersebut dilakukan oleh ABRI saat itu dan tidak terdapat kejelasan penyelesaian. 
Disamping adanya represi oleh rezim dan didukung perlindungan HAM yang minim oleh Negara.

\section{d. Babak Baru HAM dalam Era Reformasi (UUD Tahun 1945 Amandemen (I-IV))}

Gelombang reformasi yang terjadi di Indonesia memicu perubahan yang signifikan mengenai HAM. Diantaranya perubahan UUD 1945 secara bertahap dan melakukan constitusional reform yang sebelumnya hanya memuat 71 butir menjadi 199 butir ketentuan. Terlihat pada perubahan kedua dan ketiga dalam Sidang MPR tahun 2000 yang meliputi HAM dalam Pasal 28A-28J. Pengaturan HAM dalam UUD 1945 merupakan komitmen negara untuk memenuhi syarat keberadaan Indonesia sebagai negara hukum ${ }^{66}$.

Dampak dari amandemen menegaskan bahwa perlindungan, pemajuan, penegakan dan pemenuhan HAM adalah tanggung jawab negara, utamanya pemerintah ${ }^{67}$, meskipun pada tahun pertama reformasi ditandai oleh konflik horizontal, antara lain di Ambon, Poso, dan Kalimantan, dimana pelanggaran hak asasi dilakukan oleh kelompok-kelompok masyarakat sendiri $^{68}$. Bahkan terdapat beberapa agenda demokrasi yang dicanangkan pasca era Presiden Soeharto, diantaranya:

1) Constitutional and rule of law;

2) Regional autonomy;

3) Civil-military relation;

4) Civil society

5) Governance structure reform, social-economic development, good governance, and ombudsman;

6) Gender;

7) Religion pluralism ${ }^{69}$.

${ }^{66}$ Majelis Permusyawaratan Rakyat RI, Panduan Pemasyarakatan Undang-Undang Dasar Negara Republik Indonesia Tahun 1945 dan Ketetapan Majelis Permusyawaratan Rakyat Republik Indonesia, Jakarta: Sekretariat Jenderal MPR RI, 2011, hlm. 166

${ }^{67}$ Lihat Pasal 28I ayat (4) UUD 1945 UUD 1945.

${ }^{68}$ Miriam Budiardjo, Dasar - Dasar Ilmu Politik, (Jakarta: PT Gramedia Pustaka Utama, 2010) hlm. 256

${ }^{69}$ Satya Arinanto, Human Rights in Context of the Historical Non-Aligned Countries Debates on Universalim and Cultural Relativism, and Current Human Rights Development in Indonesia, Makalah disampaikan pada XVI International Annual Meeting in Political Studies on "Human Rights Today: $60^{\text {th }}$ Anniversary of the Universal Declaration of Human Rights" 


\section{Penutup}

\section{Simpulan}

Sebagai penutup dari pembahasan ini, perlu untuk dikemukakan simpulan-simpulan sebagai berikut:

Dalam kehidupan berbangsa dan bernegara, salah satu aspek penting adalah keberadaan konstitusi. Hal ini bersifat fundamental karena konstitusi memuat adanya pengaturan perlindungan HAM bagi warga negaranya. Salah satu nya di Indonesia, yang dalam perjalanan sejarah terdapat empat fase berlakunya konstitusi diantara, UUD 1945, UUD RIS 1949 dan UUDS 1950, UUD 1945 dan UUD NRI 1945 Amandemen 1-4. Dalam lintasan sejarah UUD RIS 1949 dan UUDS 1950 memiliki pengaturan HAM yang begitu banyak perlindungan HAM. Hal ini salah satunya adanya faktor pasca dideklarasinya DUHAM 1948. Pada masa berlakunya UUD 1945 sebelum amandemen, muatan HAM hanya mengatur secara khusus pada satu pasal. Perubahan signifikan terjadi ketika amandemen UUD 1945 ke 2, amandemen tersebut juga mempengaruhi muatan HAM dalam UUD 1945, yaitu dengan bertambahnya pengaturan HAM dan semakin luasnya pengaturannya. Sehingga muatan HAM tidak hanya berdasarkan hak berserikat, berkumpul dan mengeluarkan pendapat namun lebih luas dan spesifik. Muatan HAM dalam UUD 1945 hasil amandemen hampir memuat segala pengaturan DUHAM 1948.

\section{Saran}

Dengan semakin luas dan kompleksitas permasalahan HAM saat ini, penegakkan HAM sangat diperlukan. Hal ini juga ditopang oleh pengaturan dalam konstitusi dan peraturan perundang-undangan yang semakin menegaskan perlindungan HAM, Khususnya pada golongan rentan yaitu anak-anak, perempuan, penyandang disabilitas dan masyarakat ekonomi rendah yang memiliki akses perlindungan HAM yang terbatas.

\section{Daftar Pustaka}

\section{A. Buku}

Arinanto, Satya, Hak Asasi Manusia Dalam Transisi Politik di Indonesia, Jakarta: Pusat Studi Hukum Tata Negara Fakultas Hukum Universitas Indonesia, 2008

Anwar, C. Teori dan Hukum Konstitusi, Malang: In-Trans Publishing, 2011

Asshiddiqie, Jimly. Konstitusi dan dan Konstitusionalisme, Jakarta: Konstitusi Press, Jakarta, 2005 
Jimly, Pengantar Hukum Tata Negara Jilid II, Jakarta: Sekretariat Jendral dan Kepaniteraan Mahkamah Konstitusi Republik Indonesia, 2006

Atmadja, Dewa Gede, Hukum Konstitusi Problematika Konstitusi Indonesia Sesudah Perubahan UUD 1945, Malang: Setara Press, 2010

Budiardjo, Miriam Dasar-dasar Ilmu Politik, Cetakan Keempat, Jakarta: Gramedia Pustaka Utama. 2010

Darmodihardjo, Dardji dan Santiaji, Pancasila, (Usaha Nasional, 1981

Effendi, A. Masyhur Perkembangan Dimensi Hak Asasi Manusia (HAM) dan Proses Dinamika Penyusunan Hukum Hak Asasi Manusia (HAKHAM), Ghalia Indonesia, Jakarta, 2005

El-Muhtaj, Majda Hak Asasi Manusia dalam Konstitusi Indonesia, Jakarta: Prenada Media, 2005

Majda, Dimensi-Dimensi HAM Mengurai Hak Ekonomi, Sosial, dan Budaya, Jakarta: Rajawali Pers, 2008

Jacques Rousseau, Jean, Du Contract Social, Terjemah Nino Cicero, Perjanjian Sosial, Cetakan Kedua Jakarta: Transmedia, 2009

K. Smith., Rhona et. Al, Hukum Hak Asasi Manusia, Yogyakarta: Pusat Studi Hak Asasi Manusia Universitas Islam Indonesia, 2008

Kosasih, Ahmad HAM dalam Prespektif Islam; Menyingkap Persamaan dan perbedaan Antara Islam dan Barat, Salemba Diniyah, Jakarta, 2003

Kusuma, RM. A.B. Lahirnya Undang - Undang Dasar 1945, Edisi Revisi, Jakarta: Fakultas Hukum Universitas Indonesia, 2009

Lopa, Baharudin, Al Quran dan Hak-hak Azasi Manusia, PT. Dhana Bakti Prima Yasa, Yogyakarta, 1996

M. Gaffar, Janedjri, Demokrasi dan Pemilu di Indonesia, Jakarta: Konstitusi Press, 2013

M. Hadjon, Philipus Perlindungan Hukum Bagi Rakyat Indonesia, Surabaya: PT. Bina Ilmu, 1987

Montesquieu, Spirit of Law, Terjemah M. Khoiril Anam, Dasar Dasar Ilmu Hukum dan Politik, Cetakan Keempat, Bandung: Nusamedia, 2011

Pieris, John Pembatasan Konstitusional Kekuasaan Presiden RI, Jakarta: Pelangi Cendikia, 2007

Purbopranoto, Kuntjoro, Hak-hak Asasi Manusia dan Pancasila, Pradya Paramita, Jakarta, 1982

Saraswati, LG et. Al, Hak Asasi Manusia, Teori Hukum Kasus, Jakarta: Departemen Filsafat, Fakultas Ilmu Pengetahuan Budaya Universitas Indonesia, 2006

Soemantri, Sri, Bunga Rampai Hukum Tata Negara Indonesia, Bandung: Alumni, 1992

Sunny, Ismail Hak Asasi Manusia, Jakarta: Yarsif Watampone, 2004 
Thaib, Dahlan et. al., et. al., Teori dan Hukum Konstitusi, Jakarta: PT Rajagrafindo Persada

W. Nickel, James, Hak Asasi Manusia, Making Sense of Human Rights, Jakarta: PT Gramedia Pustaka Utama, 1996

Wuryandari, Ganewati, et al., Politik Luar Negeri Indonesia di Tengah Pusaran Politik Domestik, Jakarta: Pustaka Pelajar - P2P LIPI

\section{B. Peraturan Perundang-Undangan}

Undang-Undang Dasar Negara Republik Indonesia Tahun 1945

Undang-undang Nomor 39 Tahun 1999 tentang Hak Asasi Manusia Lembaran Negara RI Tahun 1999 Nomor 165, Tambahan Lembaran Negara RI Nomor 3886.

\section{Tesis dan Sumber yang Tidak Diterbitkan}

Arinanto, Satya, Human Rights in Context of the Historical Non-Aligned Countries Debates on Universalim and Cultural Relativism, and Current Human Rights Development in Indonesia, Makalah disampaikan pada XVI International Annual Meeting in Political Studies on "Human Rights Today: $60^{\text {th }}$ Anniversary of the Universal Declaration of Human Rights" 